Original research article

\title{
Social and health care services from a public health perspective: access to social and health care services for the elderly $(60+)$ in the region of Gemer in Slovakia
}

\author{
Andrea Seberíni ${ }^{1 *}$, Miriam Martinkovičová ${ }^{1}$, Miroslava Tokovská ${ }^{2}$, Ursula Småland Goth ${ }^{2,3}$ \\ ${ }^{1}$ Matej Bel University Banská Bystrica, Faculty of Economics, Banská Bystrica, Slovak Republic \\ ${ }^{2}$ Kristiania University College, Kirkegata, Oslo, Norway \\ ${ }^{3}$ NLA University College, Oslo, Norway
}

\begin{abstract}
After the age of 60 many elderly people experience increasing health problems and have an increased need for social and health care services. Slovakia will experience an aging population and the aim of this study was to assess their future needs and analyze access to social and health care services in Slovakia.

Qualitative and quantitative data was obtained by a survey based on closed and open questions and interviewing two focus groups. Data was gained from 59 mayors of the South Gemer Region (Slovakia). The qualitative data was analyzed by phenomenological analysis and the quantitative data by descriptive statistical analysis.

Our data showed a severe capacity challenge at various public retirement homes; additionally, the national and municipal services are not fully integrated. Furthermore, we detected that the needs of elderly people are often fulfilled by next of kin.

We conclude that in the years to come there will be insufficient social and health care services in Slovakia. We recommend that the coordination of social and health care services for the elderly takes place at a national and regional level.
\end{abstract}

Keywords: Access to social and health care services; Elderly; Informal caregivers; Slovakia

\section{Introduction}

Europe's population is aging rapidly. Eurostat predicts that the age structure of the European population will change significantly within the next few decades, and Slovakia will face challenges due to an aging population (Eurostat, 2019). Today in Slovakia the old-age dependency ratio is 20 elderly to 100 active inhabitants. By 2060 this ratio will change drastically and will make the population of Slovakia one of the oldest in the European Union (Bartosovic et al., 2017; Vano, 2015). The aging population will affect the relationship between the number of children and elderly - currently there are more than 102 elderly per 100 children (Slovak Republic in Figures, 2020). The need for both short and long-term care will increase over the next few years. In Slovakia, care can be provided formally or informally.

Formal care for older people usually refers to paid care services provided by a residential institution or individual for a person in need. Informal care refers to unpaid care provided by family, close relatives, friends, and neighbors. Both forms of caregiving involve a spectrum of tasks, but informal caregivers seldom receive enough training. Formal caregivers are trained in the field, but the depth of their training varies (Li and Song, 2019). This research note provides the most recent survey data evidence of the availability of informal care and discusses the informal care in households.

Informal care forms a cornerstone of all long-term care systems in Europe. Informal caregivers are mostly women (85\%), aged between 35 and 64, who are often part of the 'sandwich generation' and provide care for multiple people (27\%) (Birtha and Holm, 2017, p. 7). The caring function of families remains the key type of care provision in the international context. Informal care is often seen as a cost-effective way of preventing institutionalization and enabling users to remain at home. However, informal care is not cost-free for individuals or the state (Pickard, 2015; Rodrigues et al., 2013). The needs of carers and the impact of providing informal care on key life outcomes such as employment, health, and wellbeing are also being increasingly recognized in academic literature and in national policies across Europe (Brimblecombe et al., 2018).

Socio-cultural determinants are a strong argument for supporting the development and sustainability of informal care for the elderly. It has been estimated that $59 \%$ of the Slo-

\footnotetext{
* Corresponding author: Andrea Seberíni, Matej Bel University Banská Bystrica, Faculty of Economics, Tajovského 10, 97590 Banská Bystrica, Slovak Republic; e-mail: andrea.seberini@umb.sk http://doi.org/10.32725/kont.2021.038 
vak population is involved in subsistence activities, accounting for the largest percentage of the population among the EU member states (Jehlička et al., 2013). In this environment, trust becomes the factor that affects human relations and the reliability of family members. In this context, seniors are an integral part of family life and institutional care is only used as a last resort.

Empirical research and analysis of access to social and health care services for the elderly has revealed persistent problems and shortcomings. To overcome these, we will focus mainly on two basic dimensions of the issue: the forms of providing social services - formal and informal care. It is necessary to reflect more deeply, seek consensus, and to re-evaluate the benefits and risks of both forms with regard to the resulting benefits for the recipients of these services, i.e. the seniors themselves. The implementation of an integrative model of social care can contribute to a solution of persistent problems with access to social and health care services.

\section{Background}

Formal care for the elderly usually refers to paid care services provided by a residential institution or individual for a person in need. Informal care refers to unpaid care provided by family, close relatives, friends, and neighbors. In most European countries, the majority of care received by those aged over 50 is informal, and about a third of the over-50s provide help with instrumental tasks and/or personal care to an older dependent person (Broese van Groenou and De Boer, 2016). Both forms of caregiving involve a spectrum of tasks, but informal caregivers seldom receive the required training. Formal caregivers are trained in the field, but the depth of their training varies. Non-formal/informal care, also known as unpaid care or family care, constitutes a significant share of the total long-term care (Hoffmann and Rodrigues, 2010; Zigante, 2018). The definition of "informal care" is broad; in our study, we take informal care to include any care or help provided to older people (family or otherwise), care provided to adults of working age, young people and children with disabilities, and people living with mental health problems.

Elderly and long-term care in Slovakia is fragmented (Ministry of Labour, Social Affairs and Family of the Slovak Republic, 2020). Care for the elderly is mostly provided within a municipal's service facilities (including outreach, outpatient, and mainly residential form). The social and health care system in Slovakia relies on informal care, which is supported by allowances for caregivers, mostly relatives or next of kin. During 2002-2004, Slovakia started decentralizing the country's social and health care services. The goal of the reforms was to decentralize services by strengthening the autonomy and responsibility of the individual municipalities and self-governing regions. Fourteen years after the reform, the social and health care system is still facing challenges (Ministry of Labour, Social Affairs and Family of the Slovak Republic, 2020).

Although industrialized, Slovakia is still intrinsically rural (Slovak Republic in Figures, 2020). Data from 'Communities Slovakia' show that there are 1,145 municipalities with a population of under 500 inhabitants, comprising $43.3 \%$ of all rural municipalities (Gajdos, 2015, p. 242). Small municipalities are often governed by a mayor without educated full-time staff. In addition, many municipalities show a lack of trained personnel, equipment, infrastructure, and financial resources to provide appropriate elderly care (Slovak Republic in Figures, 2020). This leads to challenges in the provision of formal social and health care services for elderly. Often the required social and health care is provided by relatives or next of kin (Slovak
Republic in Figures, 2020). The elderly care generally provided by family members or other non-formal caregivers sustains the system but comes at a high opportunity cost. In Slovakia, informal caregivers have the right to a reimbursement from the municipality: $€ 430.35$ monthly for working caregivers and $€ 215.18$ for caregivers in retirement (Ministry of Labour, Social Affairs and Family of the Slovak Republic, 2020). In total, Slovakia provided $€ 230,938.45$ (2019) for informal care services by individuals, the majority of whom were still working (Ministry of Labour, Social Affairs and Family of the Slovak Republic, 2020). Their absence from the labor market represents a challenge for themselves and Slovak society, affecting the scope, availability and quality of social and health care services.

This study aims to analyze the ability to access formal health and social care services for the elderly (aged 60+). The definition of "elderly" varies from country to country. In this article we have taken it to mean adults aged 60+, consistent with how the World Population Ageing (2017, p. 3) defines older adults. However, this is not to say that older adults are a homogenous group defined by a specific age, nor a challenge to the idea that age is a fluid concept. This study will also investigate the potential future needs in an urban region in Slovakia, additionally assessing recent investigations and identifying where further research is necessary.

The overall research objective is to describe the factors that determine access to social and health care services in Slovakia (the region of South Gemer) for the elderly (60+) and their needs in the years to come.

To achieve the goal of the research, we focused on three areas of questions:

1. Capacity of social and health care services today and tomorrow.

2. Availability of social and health care services today and tomorrow.

3. Collaboration of state authorities on different levels.

Based on the research objective, the study will illuminate the following partial goals:

1. The existing capacity for providing formal health care for the elderly for future needs.

2. The existing capacity for social and health care services for the elderly for future needs.

3. The national and regional collaboration on social and health care services for elderly in the years to come.

\section{Materials and methods}

This study adopts a mixed methods approach through qualitative and quantitative research. The QUAN $\rightarrow$ QUAL mixed methods design included: applying a systematic process for selecting participants for qualitative follow-up, elaborating on unexpected quantitative results, and observing interaction between qualitative and quantitative study strands (Ivankova, 2014). The data for this study is based on a survey with open and closed questions (Groves et al., 2013) and focus group interviews (Green and Thorogood, 2018).

\section{Survey with open and closed questions}

The study is based on a written survey with 21 closed and open questions. The questionnaire was emailed to 59 recruited mayors from Slovakia. The survey ran from October 2019 to October 2020. Only 45 mayors (76\%) completed the question- 
naires, and their data was included in the study. Answering the questionnaire took approximately 20 minutes. The survey was followed up by interviews with 2 focus groups, with a total of 30 participants (group 1: 14 participants; group 2: 16 participants).

Data was provided anonymously. No identification of the municipality or person can be made. Respondents received an ID number between 1 and 45, depending on the time of arrival of the questionnaire.

\section{Focus group interview}

Two moderators (AS, MM) held the role of principal moderator and organised the discussion. One assistant took extensive notes during the discussion. The focus groups were based on methods described by Krueger and Casey (2014). Focus groups, due to their synergistic nature, often produce data that is seldom produced through individual interviews. They can result in powerful interpretive insights and provide access to the social interactional dynamics amongst specific groups of people (Kamberelis and Dimitriadis, 2011), thus distinguishing themselves from other qualitative methods. The 30 participants showed an equal gender distribution. Nonverbal communication was also noted. Digital recordings were helpful in gathering information on minor voice nuances, tone, pauses and feelings.

The discussion guide comprised questions regarding formal care capacity (today and in the future) and the collaboration of public offices and municipalities. The focus group interviews lasted approximately 1 hour and 15 minutes and were conducted between October 2019 and October 2020.

\section{Data analysis}

\section{Survey}

After collection, the data was analyzed by statistical calculation or phenomenological analysis (Wilson, 2015) by two of the authors (AS and MM). Based on the data received, a questionnaire for the focus group interviews was developed.

\section{Focus group interview}

The analysis is based on transcribed interviews consisting of notes and digital recordings (Green and Thorogood, 2018). A qualitative content analysis was undertaken to identify the main themes and relationships among these themes (Graneheim et al., 2017).

Data analysis was performed by three authors (AS, MM, $\mathrm{MT}$ ). The standards of analysis were in accordance with Kvale and Brinkmann (2015): understanding of self, critical understanding based on common sense, and theoretical understanding. Understanding of self is the participants' commentary, while critical understanding is the researchers' interpretations of this commentary. The researchers' interpretation has a broader framework of understanding than the participants'. In a theoretical understanding, the theoretical framework has to be considered in addition to previous research studies in order to broaden the perspective.

Transcripts were reviewed to identify specific experiences. Initial analysis of the transcripts resulted in some temporary themes that originated from the interview guide and the intent of the study (Krueger and Casey, 2014). Thereafter, a theoretical interpretation was performed (AS, MM, MT, USG) so the transcripts could be systematized to meaningfully cover the various themes and sub themes. Together, it was decided which commentaries were to be chosen in order to shed light on the relevant themes that came forth in the analysis.
The analysis of data showed that the main categories were: population forecast, capacity, availability, and collaboration.

\section{Research criteria and assumptions}

This study is based on a pilot survey regarding informal care for the elderly. In the quantitative part of the analysis, we were able to provide an overview of the number of elderly people in the selected region and of available care for the elderly in the region of South Gemer (Slovakia).

The informants in the study were all mayors, who hold key information about the scope and challenges in health and social care for elderly people in the region.

The data in this study was collected during a 12-month period, commencing in October 2019.

\section{Ethics}

The study procedures were carried out in accordance with the Declaration of Helsinki. Ethical approval was granted by the research trainee team's University Ethics Committee. Before including participants, information about the study was provided and informed consent obtained. All participants were guaranteed that their information would be anonymized; they were also guaranteed the right to withdraw their data at any time before publication.

\section{Results}

The analysis showed that the results shed light on the: (1) Aging population (population forecast), (2) Formal and informal care capacity for seniors in the South Gemer Region, (3) Availability of social and health care services, and (4) Cooperation of municipalities.

\section{Aging population (population forecast)}

Currently, one of the most significant social problems is an aging population - which has a significant socioeconomic impact on all of society. The demographic curve in Slovakia has been unfavorable for some time, in common with other member states of the European Union and global trends. As can be seen in Table 1, the population in the South Gemer Region is aging.

Slovak Republic in Figures (2020) has stated that this trend will continue in Slovakia for the years to come. This unfavorable indicator is related to the planning and development of social and health care services in the future, the mapping of informal care, the consequent increase in formal care capacity, and the availability of social and health care services, provided that inter-ministerial and inter-municipal cooperation is improved.

\section{Formal and informal care capacity for seniors in the South Gemer Region}

Data from the survey (qualitative part) and the focus group interviews showed that the existing capacity for the provision of formal care for seniors in the South Gemer Region is insufficient today - and will not be sufficient in the future without adjustment. Participants considered this:

"Our southern Gemer Region is considered an underdeveloped region. We have insufficient capacities of social service providers. When a senior aged 65 wants to see a doctor, he can't call a transport service to take him there, because there is no such service in our municipality. So, he has to take 2 or 3 buses to get there" (woman, 58 years, participant at the focus group).

The participant of the second focus group explained: "I also consider the deteriorating health of seniors to be the biggest prob- 
Table 1. Slovakia: Population 60+ depending on social and health care services (selected municipalities $=\mathbf{M}$ )

\begin{tabular}{|c|c|c|c|c|c|}
\hline District in Slovakia & Number of municipalities & Population $60+$ in 2017 & $\%$ & Population $60+$ in 2018 & $\%$ \\
\hline M I. & 5 & 69 & 5.2 & 80 & 6.0 \\
\hline M II & 5 & 52 & 3.9 & 56 & 4.2 \\
\hline M III. & 9 & 962 & 73.0 & 947 & 71.3 \\
\hline M IV. & 6 & 16 & 1.3 & 16 & 1.2 \\
\hline M V. & 20 & 218 & 16.6 & 229 & 17.3 \\
\hline Total & 45 & 1317 & 100.0 & 1328 & 100.0 \\
\hline
\end{tabular}

lem of our village and we do not have enough formal care such as social and health services - a doctor or flexible nursing care in the village or in the surroundings that would make their lives easier" (man, 49 years, Focus group participant).

Another participant (man, 61 years) wrote: "The retirement home for seniors is $50 \mathrm{~km}$ away from our municipality, and if you look at the waiting list the senior has no chance to get in there. Preference is given to seniors who have a permanent residence in the town/municipality where the retirement home is located."

Formal care capacity is unavailable for several reasons. This argument was repeated often: "We don't have the financial means to set up a transport or care service. We receive a low budget from the Ministry, which covers the necessities in terms of the administration and maintenance of the municipality. We see that it is needed, but unfortunately we do not have the money to do it" (woman, 52 years, Focus group participant).

Furthermore, the quantitative survey data showed that 27 out of 45 mayors confirmed a current shortage of social and health care services. Today's limitation of capacity was confirmed during focus group interviews.

There is also an urgent need for comprehensive services. The participating mayors pinpointed the importance of social and health care services.

"They come to ask how we can help them with their grandparents, because they need care assistance or health care. We see the necessity of having such a service, but unfortunately we do not have the capacity or finances to set one up" (man, 47 years, Focus group participant).

"It is not possible to divide health and social care services for the elderly. Many times, they need to have wounds treated, insulin injected; but they also need a companion, who will help them with shopping, cleaning, and activities such as dressing, washing. We consider it important to provide comprehensive services, not only socially but also health wise" (man, 56 years, Focus group participant).

The mayors evaluated the urgent need for comprehensive services at 8,54 points on scale of 1 (not important) - 10 (very important).

Informal caregivers fill an important gap in the social and health care provision and provide primary assistance on a long-term or temporary basis to one or more family members, or to someone in their immediate circle.

"Since... we lack social and health care services for the elderly, often their children (who are in retirement age) provide 24/7 help... They receive a car allowance, and the problem is that the senior is cared for by a senior who will themselves need help soon" (man, 42 years, Focus group participant).

Informal caregiving has a strong gender dimension: two thirds of informal caregivers are women, whereas men often only become carers at an older age. The mayors shared their various experiences with the quality of informal care:
"Another problem... is the quality of informal services provided. We cannot follow this from the level of municipalities. There are often relatives as informal caregivers... which mayors are unable to control. Some informal caregivers received a car allowance and did not use the car for the senior at all, and we find that terrible" (woman, 58 years, Focus group participant).

Data from both the qualitative part of the survey and the focus group interviews show an insufficient service and care capacity, which is the most important determinant that affects the availability and the quality of formal care. Other determinants were the age of caregivers, age of recipients and care allowances. Furthermore, most of the informal caregivers were retired.

\section{Availability of social and health care services}

The availability of social and health care services is an important criterion when seniors choose a retirement home. As a result of changes in the demographic, the system is not adequate, particularly as the demand for long-term care services is increasing (and especially for seniors). Mayors noted that even this is a big challenge for municipalities and seniors and their relatives. A participant (man, 45 years) of the qualitative part of the survey noted:

"We see long waiting times for retirement homes as a problem. Some seniors from our municipality have been waiting for a year or two and some will not even live to see it (...). There are private retirement homes available, but seniors have no money; they are incredibly expensive. So, seniors stay lonely at home."

Another participant (man, 59 years) explained: "The capacity of the retirement homes is insufficient. Seniors are registered on the waiting lists. In the best case they are waiting for a place in a retirement home for only a few months; in the worst case they can't be helped. It is also frustrating for us mayors. We would like to help our citizens but... you know."

Another participant (woman, 61 years) from the focus group added: "My husband waited for a retirement home for two years, and in the meantime his condition worsened. We put him in a private retirement home, but the whole family had to contribute; the price was very high and my husband's income was insufficient."

Our data shows an unsatisfied demand for social and health care services. The availability of places in residential homes depends on the death of a resident. However, if the social services facility provides quality services, clients live longer, meaning others who need the service will not live to receive it. This paradox of availability of services is not solely based on insufficient capacity, but also on the location of the retirement homes, other types of social and health care services, and the income of the family.

Another challenge is the availability of doctors for citizens in the municipality in this region. Seniors suffering from chronic diseases or mental health problems need to have reg- 
ular contact with a doctor or nurse at, or near, their place of residence. In this region, digital health care services are not developed due to insufficient mobile coverage and weak digital literacy of seniors. A participant (man, 49 years) from the qualitative part of the survey noted:

"We have a problem finding doctors, not only in the municipality but also in the district. Nobody wants to come to work with us. So we have retired doctors. We have no representatives for them."

A focus group participant (man, 52 years) described his own situation in connection with health care services: "Our medical centre equipment is desperate. We have no money for new X-rays, new devices. Everything is outdated and sometimes non-functional. Some people travel 50-60 km to see doctors."

Table 2 is based on the data from the quantitative part of the survey. Our findings show the pointers of availability of social and health care services for the elderly.

Table 2. Indicators for availability of social and health care services

\begin{tabular}{lc} 
Pointer & $\begin{array}{c}\text { \% of responses } \\
\text { (45 municipalities) }\end{array}$ \\
\hline $\begin{array}{l}\text { Challenge on a municipality level (overall): } \\
\text { accessibility, quality of social and health care } \\
\text { services }\end{array}$ & 71.11 \\
\hline $\begin{array}{l}\text { Challenge on an elderly level: deteriorating } \\
\text { health and insufficient supply of services }\end{array}$ & 82.61 \\
\hline $\begin{array}{l}\text { Provided health care services: None } \\
\text { Provided social services: None }\end{array}$ & 60.00 \\
\hline $\begin{array}{l}\text { Financial support for providing care for the } \\
\text { elderly: no / none }\end{array}$ & 22.22 \\
\hline
\end{tabular}

Our data also shows that residents are dependent on informal help, cohesion, and the family as traditional tools of informal care in Slovakia. At the same time, local governments have neglected to plan or create a strategy - despite knowing the mayors are critical to the system of elderly care.

42 of the 45 mayors said they do not have any social and health care service plans. On the other hand, the same mayors evaluate the availability of social and health care services for seniors in their community with an average of 4.26 points, on a scale from 1 bad - 10 excellent.

\section{Cooperation of municipalities}

Cooperation can be seen as a criterion for evaluating the level, quality, and availability of social and health care services for the elderly. This is because Slovakia is predominantly rural, with a high number of small and very small municipalities. Cooperation between such municipalities is seen as an opportunity for the combined forces to achieve better efficiency and quality of monitored services. The processed results are provided in Table 3.

Table 3. Cooperation between municipalities in the care of the elderly

\begin{tabular}{lc} 
Pointer & $\begin{array}{c}\text { \% of responses } \\
\text { (45 municipalities) }\end{array}$ \\
\hline $\begin{array}{l}\text { Cooperation (past or current) in the provision } \\
\text { of social or health care services: no/none }\end{array}$ & 66.66 \\
\hline $\begin{array}{l}\text { Collaboration with municipalities in the area } \\
\text { (municipal office, social services, health centre) }\end{array}$ & 11.11 \\
\hline
\end{tabular}

Table 3 is based on the survey, where the 45 mayors describe little or no cooperation between municipalities. Data gained from the focus group elaborates upon this finding and mentions the existing potential but lack of experience in this area. In addition, difficulties such as achieving common goals, lacking co-financing and the lack of professional staff were mentioned in the focus group interviews.

Lack of financial support in the municipal budget was confirmed by $86.66 \%$ as the biggest challenge for collaboration (survey data). In addition, geographical fragmentation (low population density) and a high number of municipalities with a small number of predominantly older inhabitants require joint efforts, an integrated approach and cooperation in the provision of social care services for the elderly. For these reasons, such a practice is unsustainable in the long run and this situation needs to be addressed.

\section{Discussion}

The aim of this study was to analyze access to social and health care services in a selected region of Slovakia for the elderly, and their future needs. The participants of the survey and focus group interviews experienced several challenges in connection to this topic.

The formal care capacity and the availability of social and health care services for the elderly does not cover the needs of either today or tomorrow. Essential care is being provided informally. The depopulation of regions due to labor mobility means that the elderly are being taken care of by other elderly people, often their retirement-aged adult children. Almost half of informal caregivers are at an economically active age. Not having these people in the labor market is a loss for them and for society. The migration of young people to study and work, together with the isolated nature of rural settlements, increases the risk of the phenomenon of lonely seniors and becomes a serious argument for strengthening preventive and screening activities. The economic situation of households also affects the provision of long-term care services; according to our results, seniors do not have enough of their own resources to solve the problem of caring for themselves.

These trends are influenced by several factors, including long-term family care, the unavailability of public care providers and the price of formal services. According to Katreniakova et al. (2019, p. 36), long-term care in Slovakia was provided at home by one or more family members (together $71.0 \%$ ), with almost two thirds (57.5\%) of informal carers not receiving an assistance care allowance. Another factor might be the care tradition of Slovak households, which is stronger in rural areas than urban areas. As Slovakia is perceived as predominantly rural, family values and attitudes are significantly influenced by intergenerational responsibility and the feeling of obligation to provide for their parents (or disabled household members). These traditions might affect the extent of informal care (Martinkovičová and Kika, 2016). We agree with the authors (Ślusarska et al., 2019; Stojak et al., 2019; Waniger et al., 2019) whose research shows that family caregivers frequently bear the responsibility of aiding in the instrumental activities of daily living and locating resources - often while raising their own families.

Since 2012, Slovakia has focused on the development of adequate social and health care services, to create and secure conditions for all citizens who depend on assistance in the natural social environment of their community. This process also 
includes knowledge transfer on a local, regional, national and international level.

Currently there is a multi-level system of long-term care services in Slovakia that is not interconnected. Thus there is no system addressing the individual situation for those in need of assistance. Health and social care services operate as two separate systems.

Slovak social services are regulated by the Social Services Act no. 448/2008, one of the legislative standards for longterm care. Social services aim to prevent, solve or mitigate the unfavorable social situation of a person, their family or community. Currently, social services for seniors are provided mainly in senior living facilities, specialized facilities and social service centres. Outpatient social services are provided for seniors mainly through home care services. The healthcare system for seniors in Slovakia is also provided within the structures of the health system (Act 576/2004 Coll.), primarily aimed at persons with chronic diseases and seniors in need of special geriatric care. This is mainly provided through home nursing agencies, daily care and institutional care (long-term care departments, geriatric and palliative departments in hospitals), and in specialized healthcare facilities, especially longterm ones: psychiatric hospitals, nursing homes and hospices. All these types of healthcare are are financed by health insurance companies, mainly on a flat-rate basis.

Outside the system, the majority of care for seniors is provided by their relatives. It takes place mainly in the home environment and is supported by a care allowance (Act 447/2008 Coll.). Although central government (represented by the Ministry of Labor, Public Affairs and Family, and Ministry of Health) creates legislation at the national level, provision of services to citizens is competitively split between regional and local municipalities. Self-governing regions in Slovakia, i.e. regions with a population ranging from 560,000 up to 820,000 , are mainly in charge of residential social services. The responsibility for providing outpatient social services has been shifted to the level of municipalities. The municipality is mainly responsible for: (i) Preparation of a community plan for social services and creating conditions to support community development; (ii) Provision of social counselling and selected outpatient and residential social services.

Although the transfer of responsibility was a logical step in bringing services closer to the citizen, the great fragmentation of responsibility among small municipalities does not allow for a comprehensive system of long-term care for the elderly. Moreover, the transfer of responsibility did not result in an obligation for municipalities to provide these services; most municipalities, due to insufficient personnel and skills, provide these services at an insufficient level, or not at all. Citizens must therefore apply for services through their self-governing region, which only provides residential services.

These inadequacies in the system of long-term care are compensated by informal care. This represents a major risk in the long run.

\section{Strengths and limitations of the study}

The main strength of this study is the large number of participants and the high return rate (76\%), which increases its validity. There are limitations; the analysis of formal and informal caregivers in the household requires caution. However, these findings could prove useful for developing national legislation and the further scaling up of elderly care integration across the Banská Bystrica region and other parts of Slovakia. The data in this study is based on a pilot survey realized in the region of South Gemer in Slovakia, which combined quantitative and qualitative methods. The southern Gemer area was selected as a result of a rigorous screening and consultation process. This study obtains data from one specific area and we cannot generalise this information. Another limitation is the cross-sectional design of the survey; there was no follow-up period for the participants. The survey measures attempted to control a wide range of variables related to the mayors' experience, but unmeasured misleading factors are not controlled.

\section{Conclusions}

We conclude that the existing capacity of social services is insufficient for the coming years and it does not cover the current needs of seniors. Waiting lists for retirement homes are extremely long, and seniors must wait several months, sometimes years, to be provided with social and health care services. The high number of applications for accommodation in residential facilities is also influenced by the lack of preventive and outpatient services at local level. These services are currently unable to accommodate the needs of seniors and attend to them in their home environment.

The current infrastructure of long-term care services in such a spatially fragmented system is insufficient in all areas for outpatient and residential social services. Municipalities are not required to provide outpatient social services but may do so voluntarily. According to the mayors, however, municipalities lack financial resources for this type of service.

We conclude that formal health and social services in Slovakia today (and in the future) do not provide the necessary services for an aging population. We found an aging society, insufficient capacity, unavailability in certain areas, and that the informal caregivers age was high. Our data shows the urgent need to systematically set up measures to promote integrated care, and to develop a model for quality insurance for services to the elderly.

\section{Authors' contributions}

AS, MM, MT designed the first version of the questionnaire, which was then corrected and improved by USG. AS and MM designed the study and wrote the protocol. AS, MM and MT oversaw all aspects of the research, conducted the analyses and produced the first draft of the manuscript. USG drafted and substantively edited all drafts of the manuscript. AS and $\mathbf{M M}$ analyzed the data. MM, MT and USG contributed to the interpretation of the data. AS, MM, MT and USG critically revised the manuscript for important intellectual content. AS takes responsibility for the integrity of the data and the accuracy of the data analysis. All authors contributed to and have approved the final manuscript.

\section{Ethical aspects and conflict of interests}

The authors have no conflict of interests to declare.

\section{Funding}

This research paper originated as partial fulfilment of a pilot research project and with the support of the community-based social service centres as a tool of multi-level partnership for providing long-term care in Slovakia, a project financed by the European Commission, DG Employment, Social Affairs and Inclusion, VP/2019/003. 


\section{Sociálna a zdravotná starostlivost' z pohl'adu verejného zdravia: prístup $\mathbf{k}$ sociálnym a zdravotným službám pre seniorov $(60+)$ v regióne Gemer na Slovensku}

\section{Súhrn}

Po šest'desiatom roku života má mnoho starších l'udí stále väčšie zdravotné problémy a zvyšuje sa ich potreba využívania sociálnych a zdravotných služieb. Slovensko čaká rýchle starnutie obyvatel'stva a práve preto ciel'om tejto štúdie bolo zhodnotit' z toho vyplývajúce potreby seniorov a analyzovat' prístup k sociálnym a zdravotným službám na Slovensku.

Kvalitatívne a kvantitatívne údaje boli získané prieskumom založeným na uzavretých a otvorených otázkach, ktoré boli kladené metódou Focus groups. Údaje boli získané od 59 starostov regiónu Južný Gemer (Slovensko). Kvalitatívne údaje boli analyzované fenomenologickou analýzou a kvantitatívne údaje deskriptívnou štatistickou analýzou.

Naše údaje poukazujú na fakt, že Slovensko má nedostatočnú kapacitu v zariadeniach sociálnych služieb pre seniorov. Služby na národnej a regionálnej úrovni nie sú plne integrované. Ďalej sme zistili, že potreby starších l'udí sú často plnené najbližšími príbuznými.

Konštatujeme, že v nasledujúcich rokoch bude na Slovensku nedostatočná sociálna a zdravotná starostlivost'. Odporúčali by sme koordináciu služieb sociálnej a zdravotnej starostlivosti o seniorov, ktorá by sa uskutočňovala na národnej a regionálnej úrovni.

Kl'účové slová: neformálni opatrovatelia; prístup k sociálnym a zdravotným službám; seniori; Slovensko

\section{References}

1. Act No. 576/2004 on health care and on services related to health care [zákon o zdravotnej starostlivosti, službách súvisiacich s poskytovaním zdravotnej starostlivosti a o zmene a doplnení niektorých zákonov]. In: Zbierka zakonov, 2004-1101, čiastka 243, pp. 5238-5424.

2. Act No. $448 / 2008$ on social services [Zákon o sociálnych službách a o zmene a doplnení zákona č. 455/1991 Zb. o živnostenskom podnikaní (živnostenský zákon) v znení neskorších predpisov]. In: Zbierka zakonov, 2008-11-20, čiastka 165, pp. 3844-3897.

3. Bartosovic I, Zacharova E, Zrubakova K, Gazikova E, West DJ, Costello MM (2017). Demographic Characteristics of Population Ageing in Slovakia. Clinical Social Work and Health Intervention. 8(3): 7-14. DOI: 10.22359/cswhi_8_3_01.

4. Birtha M, Holm K (2017). Who cares? Study on the challenges and needs of family carers in Europe. Families Europe, Brussel, 68 p. [online] [cit. 2021-01-22]. Available at: http://www. coface-eu.org/wp-content/uploads/2017/11/COFACE-FamiliesEurope_Study-Family-Carers.pdf

5. Brimblecombe N, Fernandez J-L, Knapp M, Rehill A, Wittenberg R (2018). Review of the International Evidence on Support for Unpaid Carers. Ann Longterm Care, pp. 25-40. DOI: $10.31389 /$ jltc.3.

6. Broese van Groenou MI, De Boer A (2016). Providing informal care in a changing society. Eur J Ageing 13(3): 271-279. DOI: 10.1007/s10433-016-0370-7.

7. Eurostat (2019). EUROPOP2019 population projections. Projected old-age dependency ratio. [online] [cit. 2021-0211]. Available at (last update 02/2021): https://ec.europa.eu/ eurostat/databrowser/view/tps00200/default/table?lang=en

8. Gajdoš P (2015). Ako sa mení vidiek na Slovensku. Bratislava: Sociologický ústav SAV.

9. Graneheim UH, Lindgren B-M, Lundman B (2017). Methodological Challenges in Qualitative Content Analysis: A Discussion Paper. Nurse Educ Today 56: 29-34. DOI: 10.1016/j.nedt.2017.06.002.

10. Green J, Thorogood N (2018). Qualitative Methods for Health Research (4th ed.) CA: Sage Publications. [online] [cit. 202101-22]. Available at: https://www.amazon.com/QualitativeMethods-Health-Research-Introducing/dp/1473997119

11. Groves RM, Fowler FJ, Jr., Couper MP, Lepkowski JM, Singer E, Tourangeau R (2013). Survey Methodology. 2nd ed. Wiley Publication, $496 \mathrm{p}$.
12. Hoffmann F, Rodrigues $R$ (2010). Informal carers. Who takes care of them? Policy Brief 4/ 2010. Vienna: European Centre. [online] [cit. 2021-01-22]. Available at: https://www.euro. centre.org/publications/detail/387

13. Ivankova NV (2014). Implementing Quality Criteria in Designing and Conducting a Sequential QUAN $\rightarrow$ QUAL Mixed Methods Study of Student Engagement With Learning Applied Research Methods Online. J Mix Methods Res 8(1): 25-51. DOI: $10.1177 / 1558689813487945$.

14. Jehlička P, Kostelecký T, Smith J (2013). Food Self-Provisioning in Czechia: Beyond the Coping Strategy of the Poor: a Response to Alber and Kohler's 'Informal Food Production in the Enlarged European Union' (2008). Social Indicators Research 111(1): 219-234.

15. Kamberelis G, Dimitriadis G (2011). Focus Groups: Contingent Articulations of Pedagogy, Politics, and Inquiry. Sage Publication.

16. Katreniakova Z, Levyova M, Nemcikova M (2019). Current Status and Needs of Changes in Long-term Care in the Slovak Republic: Informal Carers, Social and Health Services in the Field. Journal Socioterapie 5(1): 33-39.

17. Krueger RA, Casey MA (2014). Focus Groups. A Practical Guide for Applied Research. (5th ed.). CA: Sage Publications, 280 p.

18. Kvale S, Brinkmann S (2015). Det kvalitative forskingnsintervju. Oslo: Gyldendal akademisk, $384 \mathrm{p}$.

19. Li J, Song Y (2019). Formal and Informal Care. In: Gu D, Dupre M (Eds). Encyclopedia of Gerontology and Population Aging. Springer, Cham. [online] [cit. 2021-01-22]. Available at: https://doi.org/10.1007/978-3-319-69892-2_847-1

20. Martinkovičová M, Kika M (2016). Neplatená práca ako tradičný fenomén slovenských domácností. In: Uramová M, Orviská M (Eds). Neplatená práca na Slovensku, pp. 99-145. Banská Bystrica: Vydavatel'stvo Univerzity Mateja Bela Belianum.

21. Ministry of Labour, Social Affairs and Family of the Slovak Republic (2020). Správa o sociálnej situácii obyvatel'stva Slovenskej republiky za rok 2019 [The report on the social situation of inhabitants in the Slovak Republic in 2019]. [online] [cit. 2021-01-22]. Available at: https://www. employment.gov.sk/sk/ministerstvo/vyskum-oblasti-pracesocialnych-veci-institut-socialnej-politiky/spravy-socialnejsituacii-obyvatelstva/rok-2019.html

22. Pickard L (2015). A growing Care Gap? The Supply of Unpaid Care for Older People by Their Adult Children in England to 2032. Ageing Soc 35(1): 96-123. DOI: 10.1017/ S0144686X13000512. 
23. Rodrigues R, Schulmann K, Schmidt A, Kalavrezou N, Matsaganis M (2013). The Indirect Costs of Long-term Care. Research note. [online] [cit. 2021-01-22]. Available at: https:// www.euro.centre.org/publications/detail/415

24. Slovak Republic in Figures 2020 (2020). Statistical Office of the Slovak Republic. Bratislava. [online] [cit. 2021-0122]. Available at: https://slovak.statistics.sk/PortalTraffic/ fileServlet?Dokument=71b9f25c-4391-4f3e-aa65cea675479b26

25. Ślusarska B, Bartoszek A, Kocka K, Deluga A, Chrzan-Rodak A, Nowicki G (2019). Quality of Life Predictors in Informal Caregivers of Seniors with a Functional Performance Deficit. An Example of Home Care in Poland. Clin Interv Aging 14: 889-903. DOI: 10.2147/CIA.S191984.

26. Stojak Z, Jamiolkowski J, Chlabicz S, Marcinowicz L (2019). Levels of Satisfaction, Workload stress and Support Amongst Informal Caregivers of Patients Receiving or not Receiving Long-term Home Nursing Care in Poland: A Crosssectional Study. Int J Environ Res Public Health 16(7): 1189. DOI: 10.3390/ijerph16071189.
27. Vaňo B (2015). Súčasný a očakávaný populačný vývoj na Slovensku a jeho spoločenské a ekonomické dopady [Current and Expected Population Development in Slovakia and its Social and Economic Impact]. Prognostické práce 7(3): 273-293.

28. Waniger A, Gale K, DeNomie M, Nelson D (2019). Community and Caregiver Perceptions of Giving Care to Seniors. Int J Psychiatry Med 54(4-5): 307-315. DOI: $10.1177 / 0091217419860726$.

29. Wilson A (2015). A Guide to Phenomenological Research. Nurs Stand 29(34): 38-43. DOI: 10.7748/ns.29.34.38.e8821.

30. World Population Ageing (2017). Department of Economic and Social Affairs, Population Division (ST/ESA/SER.A/397) United Nations: New York. [online] [cit. 2021-01-22]. Available at: https://www.un.org/en/development/desa/population/ publications/pdf/ageing/WPA2017_Highlights.pdf

31. Zigante V (2018). Informal Care in Europe. Exploring Formalisation, Availability and Quality. European Commision. London School of Economics and Political Science. [online] [cit. 2021-03-09]. Available at: https://ec.europa.eu/social/ BlobServlet?docId $=19681$ \&langId $=$ en 